\title{
Tell Me More: Issues and Challenges
}

\author{
Harwati Hashim \\ (Politeknik Merlimau Melaka, Malaysia) \\ Melor MD Yunus \\ (Universiti Kebangsaan Malaysia, Malaysia) \\ doi:10.7575/aiac.alls.v.3n.2p.136
}

\begin{abstract}
Integration of technology into language education has become an everyday occurrence. Educational multimedia courseware as resource materials to enhance the teaching and learning of English language was produced extensively. Regardless of the cost, computers and courseware are becoming important tools for learning in institutions. Therefore, a considerable pressure is being put on the ESL teachers to make use of the courseware marvels in their lesson since the cost of the courseware is rather expensive. This paper aims to investigate the issues and challenges faced by the ESL lecturers on the use of a courseware named TELL ME MORE in a polytechnic in Melaka. Data was collected via semi-structured interviews with four ESL lecturers at the polytechnic. Findings show that the courseware is a useful tool for language learning. However, there are certain challenges that the ESL lecturers had to face such as time and lack of facilities.
\end{abstract}

\section{Introduction}

In the past, the cost of computers and courseware greatly restricted the use of computers in education. However, at present, integration of technology into language education has become an everyday occurrence. Educational multimedia courseware as resource materials to enhance the teaching and learning of English language was produced extensively. Regardless of the cost, computers and courseware are becoming important tools for learning in institutions. Therefore, a considerable pressure is being put on the ESL teachers to make use of the courseware marvels in their lesson since the cost of the courseware is rather expensive.

It is undeniable that the utilization of ICT in education has both advantages and constraints. With the use of the courseware in the English language classroom and with the integration of ICT in the teaching of the subject, it is important to ensure that the courseware really supports 
the students' learning as a learning tool; and whether the use of courseware is beneficial for a long term investment for the institution. ESL teachers cannot simply assume that the techniques, approaches and strategies that worked well in the traditional learning environment of the classroom can simply be successfully used in the environment of the ICT. In order to ensure the use of the courseware is successful, it is essential to identify the advantages as well as the challenges faced by ESL teachers beforehand. Therefore, this paper aims to investigate the issues and challenges faced by the ESL lecturers in the use of a courseware named TELL ME MORE in a polytechnic in Melaka.

\section{Literature review}

Over the decades, new technologies, including the introduction of information and communication technologies (ICT) and the extensive use of courseware in schools have revolutionised the education system. The demand for virtual learning and the use of ICT are increasing. Notably, new technologies are seen to be the key factor in helping to meet this demand. The revolution of information and communication technology (ICT) recently has made many people interested in integrating the use of computers. This includes teachers and educators from various disciplines.

There are many researchers who have carried out studies to evaluate the benefits of using ICT in education. Based on the British Educational Communications and Technology Agency (BECTA) (2005) ICT promotes greater collaboration among students and encourages communication and the sharing of knowledge. ICT gives rapid and accurate feedbacks to students and this contributes towards positive motivation. ICT tools have now removed the time and space limitation found in traditional teaching. Classroom dialogue can now extend beyond the time and space constraints of class time (Frayer 1997, as cited in Samuel \& Zaitun, 2006).

Many teachers and educators feel that the use of technology changes the dynamics of their classrooms. Numerous studies have been done to determine whether or not this is actually true. A comparative study in Malaysia between CALL and traditional teaching method conducted by Rohaya, Ashinida Afendi, Hamat \& Mohd. Shabri (2004) shows that CALL helps in improving students' linguistic skills. There are a number of researches that have been

conducted related to learning using courseware. Sander, Kerlen, Steinke, and Huk (2003), 
however, suggested that more research activities should be done to prove the impact of educational courseware on teaching and learning.

As far as language teaching is concerned, the role of the teachers will depend on the purposes of the relative importance of the individual aspects. For example, giving a high priority to an area like pronunciation, which requires intensive practice and precise feedback, will automatically heighten the role of the teacher as coach, although with the ability of audio technologies, the role can be delegated to ICT (Kenning, 2007). Therefore, it is hard to say that equipments are capable of taking over some of the teachers' function. Both the degree and quality of the teaching presence vary considerably across CALL software, and, as with a real teacher, the teaching presence can come in different forms (Hubbard, 2006).

Chong, Chee Keong, Sharaf Horani, and Daniel (2005) conducted a study on 111 respondents to investigate the use of ICT in Mathematics teaching and found that teachers are not fully utilizing the ICT facilities in their teaching. Six major barriers were identified: lack of time in the school schedule for projects involving ICT, insufficient teacher training opportunities for ICT projects, inadequate technical support for these projects, lack of knowledge about ways to integrate ICT to enhance the curriculum, difficulty in integrating and using different ICT tools in a single lesson and unavailability of resources at home for the students to access the necessary educational materials. Melor (2007) conducted a study on English teachers in technical schools in Peninsular Malaysia to explore in detail ESL teachers' use of ICT, attitude to ICT and competence in the use of ICT. The analysis shows that the teachers' attitude to the use of ICT in teaching is positive. The analysis also provides evidence that the teachers perceive that using ICT has many benefits to language teaching and learning. However, it is also found that the real usage of ICT is low due to teachers' low ICT competency especially in some specific areas of ICT and also some other related factors such as lack of access, unavailability of the computers and lack of time.

\section{Methodology}

This study employed a qualitative design using semi-structured interview to obtain the ESL lecturers' view on the use of the TELL ME MORE courseware for the learning of English language. Four female ESL lecturers with a minimum of one year experience to a maximum of six years experience of teaching in a polytechnic in Melaka participated in the semistructured interview. All of them possess a degree in teaching English as second language 
(TESL) from various local universities. The names of the ESL lecturers mentioned in the discussion are pseudonym.

\section{Findings}

This section presents findings based on the interview sessions with four ESL lecturers who are teaching semester one students. The aim is to look into their perceptions on the use of the TELL ME MORE courseware in a polytechnic in Melaka. The findings are discussed according to issues and challenges.

\section{Issues on the use of TELL ME MORE courseware for the learning of English language}

The ESL lecturers were asked on their opinion regarding the practice provided in TELL ME MORE. There were two different views given by the lecturers. ESL lecturer B believed that the students get enough practice in TELL ME MORE because there are a lot of activities provided. She said,

... there are lots of activities that they can get in the courseware such as communication practices, pronunciation, crossword puzzles and many more. (ESL lecturer B)

The ESL lecturers were also asked on their opinion about the level of difficulty of the courseware for their students. All lecturers commented that the courseware is at the appropriate level for their students' proficiency. They also mentioned that there is no problem regarding the level of difficulty because the courseware provides different levels of difficulty for different levels of proficiency. Below are their responses;

The beginner can choose the beginner level, the intermediate can choose the intermediate level and same goes to the advance where they can choose the advanced level. (ESL lecturer A)

Basically in the courseware, there are certain proficiency levels which are beginner, intermediate and advance so the students can choose which level that is appropriate with their level of proficiency. (ESL lecturer B)

... TELL ME MORE has different set for different level of proficiency so the students can choose which one is the most suitable for them. (ESL lecturer C)

I think such problem doesn't occur because TELL ME MORE has three different levels which are beginner, intermediate and advance. So weak students can choose beginner, moderate students can choose intermediate and the good students can choose advance level. Yes, it is at the appropriate level of difficulty for my students. (ESL lecturer D)

All four ESL lecturers were asked on the possibility of their students remembering what they have learnt using TELL ME MORE. According to ESL lecturer A, she believed that students 
are able to remember what they have learnt in the courseware because the activities are fun and suitable for their culture and background knowledge. She said, "... the activities provided in the courseware are quite fun and it is suitable for their culture and background knowledge." The researcher then probed ESL lecturer A's response when she mentioned about culture and background knowledge. She explained,

\begin{abstract}
What I meant by their culture is that all activities in the courseware are daily activities which they do every day and the activities are not too culturally based where most of the videos used are displaying modern living. As far as their background knowledge is concerned, all activities are familiar to them and they have learnt it in their modules especially on the communication activities.
\end{abstract}

The ESL lecturers' opinions on the possibility that their students practice what they have learnt in TELL ME MORE outside of the classroom were also obtained. Basically, ESL lecturer $\mathrm{C}$ believed that her students might have practiced what they have learnt in the courseware because she could see some improvement in her students. She said, "...I can see that most of my students...they have improved especially in the speaking skills."

When asked about their perception on their students' attitudes toward the use of TELL ME MORE. They mentioned that their students like to use the courseware due to different reasons. The following are the responses recorded from the ESL lecturers'.

\footnotetext{
... I think they do because there are many activities or skills involve such as listening, reading, communication and so on; all in one." (ESL lecturer A). Another lecturer added, "...they definitely like to use it because they find it interesting and it is a new way of learning. (ESL lecturer B).

... I can see that they are having fun while doing the activities. Furthermore, sometimes they need something different rather than just sit and listen to their lecturer. (ESL lecturer C)
}

\title{
Challenges on the use of TELL ME MORE courseware for the learning of English language
}

Apart from the benefits, the ESL lecturers had mentioned, there were also certain challenges that they had faced in using the courseware in English language learning. ESL lecturer D felt that the students still needed guidance from their ESL lecturer especially in certain activities. Her concern was regarding the pronunciation activities which definitely need a lecturer to actually help them in pronouncing words correctly as they might be unable to get the correct pronunciation produced by the computer. This was probably due to the use of the British accent where students are not familiar with the pronunciation by native speakers. So, students might have problems in understanding the accent. She clarified, 
...they still need lecturers' guidance because some of the activities need to be explained by lecturer especially the pronunciation activities because they need their lecturer to actually pronounce the word as they cannot get the pronunciation produced by the computer. (ESL lecturer D)

Regarding the practices provided in the courseware, some of the ESL lecturers believed that students did not get enough practice in the courseware due to the time constraint. This was probably due to the limited contact hours of the English modules where they only have two hours a week. One of them claimed,

I think for two hours lecture is not enough for them to browse through all the activities...In that two hours, we have to deduct few minutes for the students to arrive at the lab, minus few minutes to switch on the computer and not forgotten few minutes that we have to spare to switch off the computer. So, overall we have only about 40 minutes to conduct the lesson. (ESL lecturer A)

With regard to the possibility that students could remember what they have learnt using TELL ME MORE, even though some positive responses were given, there were also some opposite views given by other ESL lecturers. ESL lecturer B and ESL lecturer C had a different view regarding this matter. They believed that students might be able to remember the communication activities but not the grammar part. ESL lecturer C commented,

\footnotetext{
... they should be able to remember because most of the activities are based on daily situation, especially the communication part. However, I doubt the students can remember the grammar part as the explanations are very simple. I guess low proficiency students might have problem in remembering the grammar part. (ESL lecturer C)
}

The ESL lecturers also mentioned that some of the main challenges in using the courseware were time constraint, syllabus and facilities. ESL lecturer A mentioned that because of limited time, students can only do a few exercises. She said, "...they cannot go through all. Maybe they can do a few or parts of the activities." This was probably because students only have the opportunity to use the courseware provided in the language laboratory, due to licensing where it is impossible for the students to have the courseware on their own at home. ESL lecturer C shared the same view as ESL lecturer A, as she stated, "It is hard to say...I don't think they have enough time. They need more time to go through with the activities provided." Another lecturer noted, "...we only have 2 hours a week for each class" (ESL lecturer D). This was probably because the contact hours for the English language lesson are too short. 
ESL lecturer C mentioned about the syllabus which was part of the reason why the students did not have sufficient time to use the courseware. She said, “...we also need to finish up our own syllabus because not all activities suit the requirement of the syllabus." She believed that they must teach according to the syllabus and they have to complete the syllabus. She added, "... some of the activities that can be used frequently are the pronunciation activities because we have that in our syllabus as well...and... of course some of the communication activities especially on greetings and introduction."

Besides that, one of the lecturers mentioned about the lack of facilities such as computers, and that the language laboratory was not conducive. It was also found that lecturers are not fond of using the language laboratory due to its condition. She claimed, "...our lab (language laboratory) is not really conducive as space is very limited."

The ESL lecturers were asked on their opinion about the quality of the computers in the language laboratory. Based on their responses, it can be concluded that the computers in the language laboratory were not acceptable where quality was concerned. Basically, the ESL lecturers mentioned about the lack of facilities and technical problems. ESL lecturer A mentioned that the computers were not of quality as the audio system did not function well. She also believed that they need more computers in order to fully utilize the courseware. She said,

We need more computers in the future in order to implement or to use the courseware effectively... we probably need more than 42 computers because some classes, students are more than 42 .

Another challenge highlighted by the ESL lecturers was regarding the technical aspects which were the server and the networking. The ESL lecturers responded,

\footnotetext{
...we do face some technical problems sometimes especially on the server and networking. (ESL lecturer B)

Well, sometimes we do have problem with server. So it is very unpredictable. (ESL lecturer C)

That is our main problem. There are times where the computers cannot be used because of the server or something else. (ESL lecturer D)
} 


\section{Discussion}

Issues on the use of TELL ME MORE courseware for the learning of English language

From the interview with the ESL lecturers, it was found that the English language lecturer believed that the students got enough practice in TELL ME MORE because there were a lot of activities provided such as communication practices, pronunciation and crossword puzzle. The courseware was also at the appropriate level of their students' proficiency. There was no problem regarding the level of difficulty because the courseware provides all levels of proficiency from "Beginner" to "Advanced". This would probably make the students be more motivated to learn the language. Thus, the courseware fit the students' condition in terms of their level of proficiency and motivation in learning the language. According to Chapelle, Jamieson \& Preiss (2005) criteria for CALL evaluation, learners fit will also determine their use of ICT whether the material is appropriate to their level and also whether they are anticipated in the learning activities

The results of the interview with the English language lecturers also showed that students were able to remember what they had learnt in the courseware because the activities were fun and suitable for their culture and background knowledge. This finding is in line with finding by Chapelle, Jamieson \& Preiss(2005) where the responses in the weekly questionnaires revealed that most of the students could remember some of the content of the Longman English Online (LEO) CALL materials. The use of the courseware was also found to bring positive impacts to the teaching and learning of the language. The findings indicated that the students liked the courseware and it gave positive impact to the students. It is supported by Lee (2000) who suggests that if CALL technologies are integrated appropriately, they can support experiential learning and practice in a variety of modes, provide effective feedback to learners, enable pair and group work, promote exploratory and global learning, enhance student achievement, provide access to authentic materials, facilitate greater interaction, individualize instruction, allow independence from a single source of information, and motivate learners.

\section{Challenges on the use of TELL ME MORE courseware for the learning of English language}

Regarding the challenges, the findings revealed that students still need guidance from their ESL lecturers particularly the pronunciation activities which definitely need a lecturer to actually help them in pronouncing words correctly as they might unable to get the correct pronunciation produced by the computer. This was probably due to the use of the British 
accent where students were not familiar with the pronunciation by the native speakers. So, students might have problems in understanding the accent. The students still need someone to guide them. Both the degree and quality of the teaching presence vary considerably across CALL software, and, as with a live teacher, the teaching presence can come in different forms (Hubbard, 2006).

The findings also showed that students did not get enough practice in the courseware. Reasons given were due to time constraint. This was probably due to the limited contact hours of the English modules where they only have two hours a week. This findings support findings by Nor Ashikin (2009) who found that one of the teacher-related challenges was time constraint. It is also supported by Januddin (1997) and Norin (2004) who found that time-constraint is one of the major barriers. Apart from that, the findings also revealed that students might not be able to remember the content of the courseware particularly of grammar.

There were also other several challenges that were pointed out by the ESL lecturers which were time, interface and quality of computers provided. In terms of time, there were three problems that had been identified which were syllabus, facilities and time constraint. It was also found that because of limited time, students could only do a few exercises. This was probably because students only had the opportunity to use the courseware provided in the language laboratory, due to licensing where it was impossible for the students to have the courseware at home. The findings also revealed that the syllabus was one of the challenges as well. This was because the ESL lecturers must also teach according to the syllabus and they had to complete the syllabus. Besides that, one of the lecturers mentioned about the lack of facilities such as computers, and that the language laboratory was not conducive. It was also found that lecturers were not fond of using the language laboratory due to its condition.

Apart from that, the quality of the computers in the language laboratory was also one of the challenges. Based on the ESL lecturers' responses, it can be concluded that they were not happy with the quality of the computers in the language laboratory. Basically, two main problems had been identified which were lack of facilities and technical problems such as networking and server. The ESL lecturers also believed that they need more computers in order to fully utilize the courseware. This finding complements the finding of a study conducted by Chua (2009) which reported that teachers claimed they face challenges in using 
ICT especially due to insufficient facilities. Melor (2007) reported the same finding which most of the teachers identified problems with the quantity or the organization of computers. This is also consistent with the findings of Pelgrum (2001, as cited in Melor, 2007) and Guha (2000, as cited in Melor 2007) where insufficient numbers of computers was cited as a major obstacle to the integration of ICT into teaching and learning. Another problem highlighted by the lecturers was regarding the technical aspects which were the server and the networking.

\section{Conclusion}

The findings of the semi-structured interviews have assisted the researchers to understand the issues and challenges faced by the ESL lecturers in the polytechnic in utilizing the TELL ME MORE courseware in language learning. In this study, it was found that the use of the courseware is a useful tool for language learning and it could help students in increasing their

proficiency and motivation. However, it should be noted that there are challenges faced by the English language lecturers such as time and lack of facilities that need to be taken into consideration in order to make the use of the courseware effective and successful. English language lecturers should familiarize themselves first with what the courseware has to offer. There are many benefits which can be gained from utilizing the courseware in language teaching and learning. The courseware which is equipped with multimedia features provides opportunities for students to play and participate actively in the language learning process where this makes learning via the courseware fun, enjoyable and informative to students and English language lecturers alike. In this study, it was found that the use of the courseware could help students in increasing their proficiency and motivation. Probably, with the use of the courseware, it could overcome the current problem faced by the country which is the deterioration of the level of English language proficiency among Malaysian students. It could also be a possible suggestion in helping the students to improve their English language level of proficiency and to empower the teaching and learning of English language since the teaching of Mathematics and Science (ETeMS) will revert to Bahasa Malaysia in 2012 (Malaysia Today 2009). 


\section{References}

Ashinida Aladdin, Afendi Hamat \& Mohd. Shabri Yusof. (2004). Penggunaan PBBK (pengajaran bahasa berbantukan computer) dalam pengajaran dan pembelajaran Bahasa Arab sebagai bahasa asing: Satu tinjauan awal. GEMA Online Journal of Language Studies, Vol. 4(1) 2004. http://www.fpbahasa.ukm.my/linguistics /Gema/GemaVol4.1.2004No1.pdf [18 August 2008].

British Educational Communications and Technology Agency. (2005). The Becta Review: Evidence on the progress of ICT in education. www.becta.org.uk/research/display.cfm?section=1 [23 September 2008].

Carmen et al. (2003). Use of ICTs and the Perception of E-Learning among University Students: A Differential Perspective according to Gender and Degree Year Group. Interactive Educational Multimedia, No 7 (October 2003) pp 13- 28.

Chapelle, C., Jamieson, J. \& Preiss, S. (2005). Call evaluation by developers, a teacher, and students. https://calico.org/a-133-CALL\%20Evaluation\%20 by\%20Developers $\quad \% \quad 20 \quad \mathrm{a} \% \quad$ 20Teacher $\% 20$ and\%20Students.html [10 January 2009].

Chong, Chee Keong, Sharaf Horani \& Daniel, J. (2005). The study on the use of ict in mathematics teaching. Malaysian Online Journal of Instructional Technology (MOJIT) Vol. 2 No.3 pp 43-51 http://pppjj.usm.my/mojit/article/pdf/Dec05/06-

A_Study_on_the_Use_of_ICT_in_Mathematics_Teaching-final.pdf

Chua Pei Lin. (2009). The use of ICT in learning English as a second language among the urban school students in Kuala Terengganu. Master's Thesis, Faculty of Education, Universiti Kebangsaan Malaysia : Bangi.

González-Lloret, M. (2003). Designing task-based call to promote interaction : en busca de esmeraldas. Language Learning and Technology. January 2003, Volume 7, Number 1, pp. 86-104. http://llt.msu.edu/vol7num1/Gonzalez/ [20 December 2008].

Hubbard, P. (2006). Evaluating CALL software. Chapter 13 from L. Ducate \& N. Arnold (eds) (2006). Calling on CALL : From Theory and Research to New Directions in Foreign Teaching. San Marcos : CALICO. Pre-publication copy.

Janudin Awang. (1997). Kekerapan penggunaan teknologi pendidikan oleh tenaga pengajar di sekolah menengah dalam kem angkatan tentera. Master's Project Paper. Universiti Kebangsaan Malaysia, Bangi.

Kenning, M. (2007). ICT and language learning : from print to mobile phone. New York: Palgrave Macmillan

Lee, K. W. (2000). English teachers' barriers to the use of computer-assisted language learning.

The Internet TESL Journal. http://iteslj.org/Articles/Lee-CALLbarriers.html. [3 January 2008].

Malaysia Today. (2009). Teaching of Sciences and Mathematics back to Bahasa Melayu. http://mt. m2day.org/2008/content/view/24075/84/ [2 November 2009]

Melor Md Yunus. (2007). Factors affecting the use of information communication technologies in teaching English as a second language in Malaysia. PhD Dissertation, Faculty of Social Sciences and Law, UK: University of Bristol.

Melor Md Yunus. (2007). Malaysian ESL teachers' use of ICT in their classrooms : expectations and realities. European Association for Computer Assisted Language Learning. ReCALL 19(1): 79-95.

Nor Ashikin H'ng Abdullah. (2009). TESL teachers' utilization of ICT in teaching English. Master's Thesis, Faculty of Education, Universiti Kebangsaan Malaysia : Bangi.

Norin Mustaffa. (2004). Kemahiran, masalah dan tahap penggunaan computer di kalangan guru-guru sekolah bestari negeri Perak. PhD Thesis. Universiti Kebangsaan Malaysia : Bangi.

Samuel, R.J. \& Zaitun Abu Bakar. (2006). The utilization and integration of ICT tools in promoting English language teaching and learning: Reflections from English option teachers in Kuala Langat District, Malaysia. http://ijedict.dec.uwi.edu/viewarticle.php?id=161\&layout=html [ 12 August 2008 ].

Sander, U., Kerlen, G., Steinke, M., \& Huk, T. (2003). Evaluation of two CD-ROMs from a series on cell Biology. Cell Biology Education, 2. 